MPC MAJOR RESEARCH PAPER

\title{
TEACH THEM TO BE EXPRESSIVE: AN APPLICATION OF COMMUNICATION ACCOMMODATION \\ THEORY TO VOCAL PEDAGOGY
}

\section{MEGHAN MCKIBBON}

\author{
Dr. Dario Del Degan
}

The Major Research Paper is submitted in partial fulfillment of the requirements for the degree of Master of Professional Communication

\author{
Ryerson University \\ Toronto, Ontario, Canada
}

September 12, 2014 


\section{AUTHOR'S DECLARATION FOR ELECTRONIC SUBMISSION OF A MAJOR RESEARCH PAPER}

I hereby declare that I am the sole author of this Major Research Paper and the accompanying Research Poster. This is a true copy of the MRP and the research poster, including any required final revisions, as accepted by my examiners.

I authorize Ryerson University to lend this major research paper and/or poster to other institutions or individuals for the purpose of scholarly research.

I further authorize Ryerson University to reproduce this MRP and/or poster by photocopying or by other means, in total or in part, at the request of other institutions or individuals for the purpose of scholarly research.

I understand that my MRP and/or my MRP research poster may be made electronically available to the public. 


\begin{abstract}
There is a large amount of overlap between the disciplines of singing and communication, particularly in the area of expression. Recent science based pedagogy written by Richard Miller is considered foundational knowledge in the vocal community, however, there are concerns that this anatomically focused pedagogy prevents the development of creative and expressive singers. A thematic analysis of two of Miller's pedagogical texts was used to collect excerpts focused on the topic of expression. A second phase intention analysis revealed that the discussion of expression was largely uninstructive, providing teachers with minimal methodology. There is evidence that Miller addresses the importance of expression in vocal performance, however, his style of pedagogy does not allow for an in depth exploration of the tactics necessary for its instruction. Applying concepts from communication accommodation theory to the pedagogy will allow for the expansion of existing techniques such as modeling, convergence and divergence into the area of expression aiding vocal instructors in teaching the art of musical expression.
\end{abstract}


TABLE OF CONTENTS

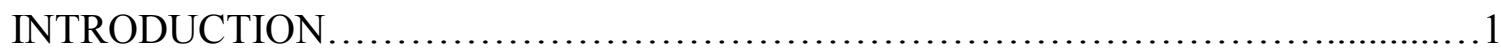

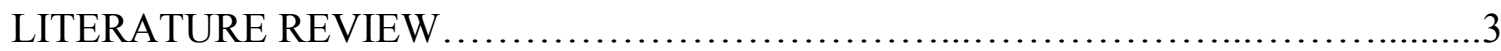

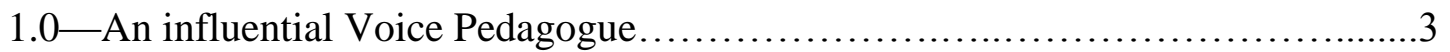

1.1-The Scientific Approach...................................................

2.0-Expression in Music.........................................................

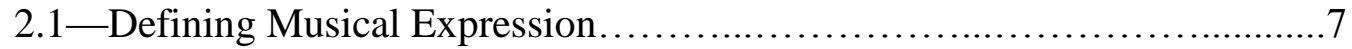

2.2-Richard Miller on Expression............................................... 8

3.0 - Communication Accommodation Theory (CAT) ...............................

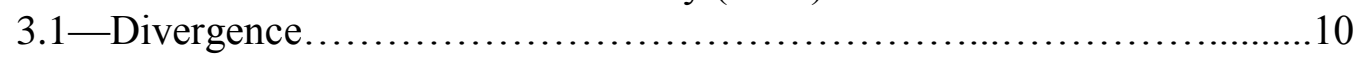

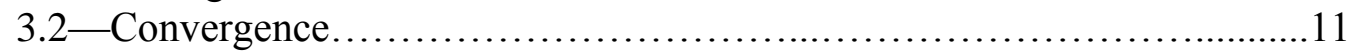

3.3 - CAT and Second Language Acquisition..............................12

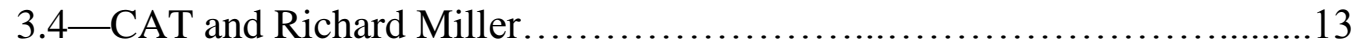

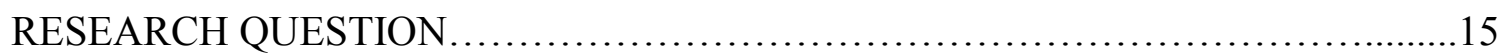

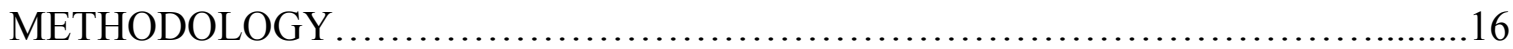

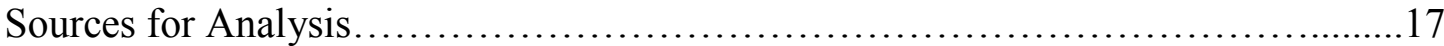

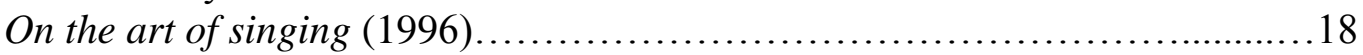

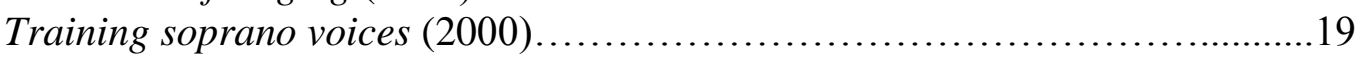

Data Collection and Thematic Analysis: Phase I...................................19

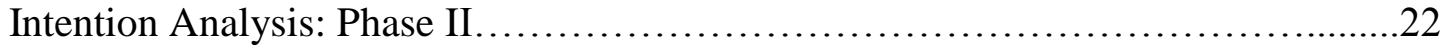

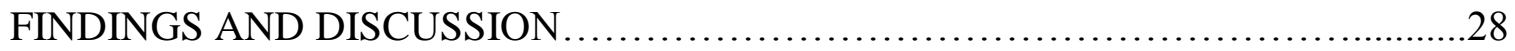

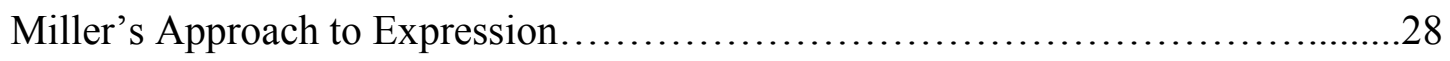

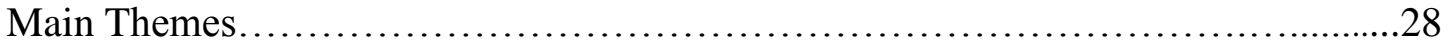

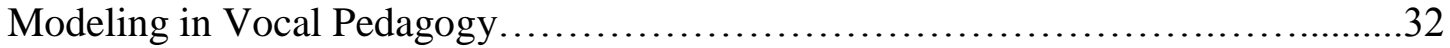

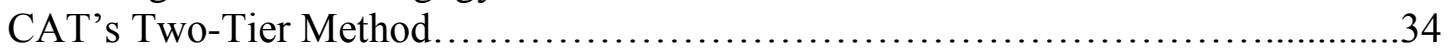

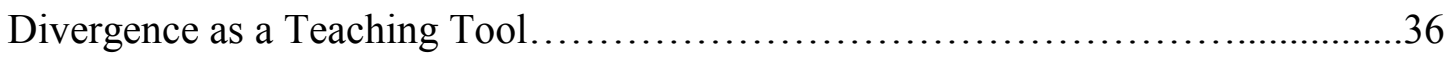

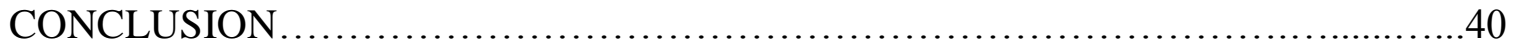

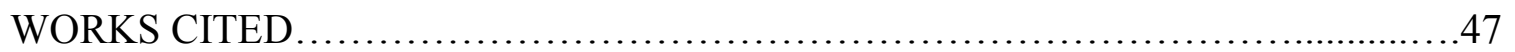




\section{LIST OF TABLES}

Table 1: Thematic Analysis Code Descriptions..................................20

Table 2: Data Collected per Code.............................................21

Table 3: Overarching Intention Themes.........................................22

Table 4: Intention Categories...............................................23

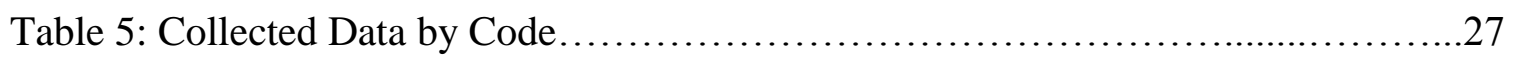

Table 6: Intention Category per Source I.......................................29

Table 7: Intention Category per Source II....................................29 


\section{LIST OF APPENDICES}

Appendix A............................................................42 


\section{INTRODUCTION}

This Major Research Paper (MRP) is inspired by the shift in the music education community that has been gaining momentum within the last decade. Since the mid 1900s, Western vocal pedagogy at the university level has been approached from a traditional standpoint, which is centered on a scientific style of instruction (Nederland, 2007:401). This scientific approach focuses on the understanding of the physical functions of the voice and singer's body (Miller, 1996). Some scholars have raised concerns regarding this scientific style of pedagogy by arguing that it does not provide adequate methods to teach the artistic and emotional components of performing (Gabrielsson \& Juslin, 1996; Geringer \& Sasanfar, 2013), due to its anatomical and acoustical focus. An essential aesthetic ingredient of a vocalist is the incorporation of expression, such as emotion, feeling, and intention, to a piece of music. However, the ineffable nature of defining and articulating expression makes it a challenging area of instruction. New research from the past decade has started to recognize and consider the connections between everyday communication and the instruction of expressive musical techniques. For example, a 2010 study recognized the use of gesture — a nonverbal communication tool-as a successful method for teaching complex vocal techniques (Nafisi, 2010). Similarly, a research initiative, directed by a faculty member at the University of Prince Edward Island, known as AIRS (Advancing Interdisciplinary Research in Singing), aims to connect the acquisition of speech to the acquisition of singing (Cohen, 2008). This is significant because in many ways music — especially singing — is a communicative act, and music's ability to communicate is already seen in industries such as therapy and advertising (Pavlicevic, 2000; Gorn, 1982). The addition of a text in many vocal pieces adds another component of communication, which further strengthens the relationship between singing and everyday speech. 
The void in the literature surrounding the instruction of expression demonstrates a need for research. The investigation into the similarities between music and speech acquisition, and the desire to enhance the instruction of the aesthetic properties of voice performance, such as expression, inform the direction of this study. This study focuses on vocal instruction at the University level in Ontario. The scope of the study was limited to Ontario due to the understanding that vocal instruction in different countries may vary based on the musical history of the culture. The University level of instruction was selected because it is at this level that the students are musically proficient, and are developing the nuanced details of a higher level performance, which includes expression. The voice syllabus of the Royal Conservatory of Music (Royal Conservatory of Music, 2012), located in Ontario, provides the expectations of University level vocalists, as well as highlights the pedagogy frequently referred to by teachers. 


\section{LITERATURE REVIEW}

The literature supporting this study has been divided into three sections. Richard Miller is the vocal pedagogue whose published work will act as the primary data for this study, and the first section of the literature review provides an in-depth look into his work. The second section focuses on the literature surrounding the instruction of expression in music. The third section examines communication accommodation theory, which acts as a lens for this study. An understanding of communication accommodation theory (CAT) provides insights that can assist instructors in teaching complex concepts of music such as expression. CAT connects the three categories of this literature review together in a way that demonstrates the connection between everyday communication and singing.

\section{0-An Influential Voice Pedagogue}

An understanding of the leading vocal pedagogy is a key ingredient in the expertise of a singing teacher. Pedagogy is based on research aimed to solve problems within an education setting, and provide instructors with a guided approach to help students achieve a desired outcome (Mortimore, 1999: 12). The weight of a pedagogical document is determined by the support it receives from the community it aims to assist. Richard Miller is a leading vocal pedagogue who has become an authority in modern vocal pedagogy due to his revolutionary approach to research. He has "advanced vocal pedagogy by synthesizing information from different fields (i.e. singers, teachers, voice students, voice scientists and health care professionals)" (Abelson \& Hicks, 2007). His desire to "bridge the disciplines of acoustics, physiology, medicine, speech and performance" has led to a new kind of vocal pedagogy that has modified the way instructors teach singing (Abelson \& Hicks, 2007). In fact, many contemporary 
music teachers consider Miller to be one of the most influential voice pedagogues globally (Edwin, 2007). His documents are widely referred to and are often cited as important resources for teachers. For example, the Royal Conservatory of Music's voice syllabus recommends all of Miller's published pedagogy, and the book Bel Canto (2003), which provides a historical overview of the Western vocal tradition, extensively cites Miller's research. However, while his approach to pedagogy has helped modernize the instruction of singing, many vocal teachers find that his approach does not support the instruction of expression, a crucial ingredient of performance. To understand where this criticism originates, a detailed look into Miller's pedagogy is needed.

\section{1-The Scientific Approach}

Miller's scientific approach applies "hard science" to the instruction of singing (Abelson $\&$ Hicks, 2007). His desire to combine the "art of singing and the science of medicine" has created a pedagogy that focuses on the anatomy of the voice (Abelson \& Hicks, 2007). The terminology in Miller's documents is technical—using specific vocabulary such as larynx, diaphragm, and resonators-requiring readers to have an understanding of the physiological components of the voice and acoustics. His focus is largely on respiration, phonation, and resonation (Kiesgen, 2007). Miller uses otolaryngology studies (that rely on equipment such as laryngoscopes, stroboscopes and recording devices) to support his research, allowing him to better understand how the voice works while undergoing different acts of singing (i.e. vowel positions and pitch) (Abelson \& Hicks, 2007). Vocal instructors must have knowledge of anatomical and acoustical science and how they apply to the teaching of voice (Miller, 1996), as the scientific approach involves teaching vocal students about the parts of the voice that are not 
visible to the eye. Miller's approach aims to assist instructors in teaching their students the anatomical components of the voice through detailed scientific descriptions and illustrations of the specific parts of the vocal instrument. It is Miller's position that vocal pedagogy involves instructing the student on the "actual physiology" of the singing action (Miller, 1996: 5-6). His approach assumes that if teachers are able to provide their students with a strong scientific and technical singing foundation, the outcome will be more skillful and beautiful singers (Kiesgen, 2007).

Scientific vocal pedagogy has become a part of the foundational knowledge of many of today's singing teachers. Therefore, Miller's pedagogy is now considered a primary resource within the vocal community. His works are respected to the extent that "university faculty are increasingly renaming and adjusting voice pedagogy courses to be in vocal science and pedagogy," and many teachers now use vocal science to "confirm or adjust their pedagogical approach" (Bozeman, 2007).

Although Miller's approach is scientific, he does advocate for the importance of musicality and artistry (Kiesgen, 2007). His intent is to help teachers familiarize students with terminology relevant to vocal pedagogy, which includes applying anatomical and acoustical information to the concepts of musicality and performance style (Miller, 1996). Yet, with the main focus of Miller's pedagogy being respiration, phonation, and resonation, there is a lack of detailed discussion regarding the instruction of expression.

Miller's scientific style of vocal pedagogy has received criticism that science based learning can interfere with the formation of artistry and the imaginative self, which are important for the development of expression in music (Abelson \& Hicks, 2007). Miller claims that 
effective expression will evolve naturally once a student has obtained a strong technical singing foundation, but this position is not always shared. Holistic vocal pedagogy is considered the contrast to the scientific approach due to its emphasis on the "primal sound" of the voice and its focus on all aspects of the person (i.e. mind, body, spirit, emotion and voice) (Chapman, 2007). Unlike Miller's desire to ensure students are well aware of the anatomical and acoustical terminology involved in singing, the holistic approach is not as strictly codified (Chapman, 2007). To understand the contention surrounding the discussion of expression found in Miller's pedagogical documents, a closer look into expression in music is required.

\section{0-Expression in Music}

Similar to everyday communication, the use of expression in a musical performance is imperative for conveying meaning. An individual usually acquires expression through everyday communication as they learn a language. Teaching expression in an artistic setting can be difficult to convey in language, making it a challenge for music educators. According to Gabrielsson and Juslin (1996), "expression is one of the least understood aspects of music, at least as far as scientific explanation goes" (68), and recent studies confirm that expression in music is one of the most debated subjects in music education (Geringer \& Sasanfar, 2013:161). For something considered to be a critical component of vocal performance, there seems to be a void in the literature of an agreed upon method of instruction. According to Geringer and Sasanfar (2013), further information regarding expression in music, and the influence of the teacher in educating a student on this concept, will "help to establish an informed pedagogical basis for this consequential aspect of music performance" (171). CAT recognizes the different methods of communication (i.e. verbal and nonverbal), and works to uncover the complex 
communicative acts taking place during one-on-one conversations. With knowledge of CAT, vocal instructors might better understand the connection between everyday communication and singing, and be able to apply this knowledge to the instruction of expression.

Unlike some of the vocal techniques used to develop a proper singing sound, creating an expressive performance includes many ineffable elements (i.e. emotion, feeling, intention), which is why it is a challenging area of instruction. Similar to a conversation, in every musical performance there is a distinct intent or meaning that is being conveyed. In vocal music, these emotional intentions can come from directions from the composer to the lyrics. Expression in music differs from everyday conversations in that emotion meanings in music are often prescribed and rehearsed prior to performance.

It is this gap in the literature regarding the lack of methodology for instruction on expression that has inspired the direction of this study. Interestingly, in a study conducted by Lukkau (2004), when music teachers were asked to rank their willingness to try new teaching strategies aimed at expressive skills on a scale of zero (absolutely) to ten (never), the mean rating was 0.94 (52). This response demonstrates that there is a desire for teaching methods in the area of expression.

\section{1—Defining Musical Expression}

Defining expression has been an ongoing issue across multiple disciplines (Ekman, 1997). The debate centers on whether expression is considered "a form of communication or an involuntary expression of an internal state" (Ekman, 1997: 333). De Poli (2004) states that expressive communication in music involves the participation of the composer and the 
performer. Since a singer is performing a work with a predetermined meaning from a composer, the emotion being expressed is predetermined and not involuntary.

More specifically, Juslin and Laukka (2003) state that in the practice of vocal music, expression represents the communication of emotions. They have determined that the both verbal and nonverbal aspects of expression are used to convey meaning during a performance (Juslin \& Luakka, 2003: 770). Based on this research, the definition of expression for this study will be the verbal and non-verbal communication tactics purposely employed by vocal performers to communicate emotional meaning to a listener.

\section{2-Richard Miller on Expression}

As a general comment on expression, Miller suggests that with a strong technical foundation in singing, a student will naturally be able to achieve successful expression. He states, "it will be the sound that is most efficiently produced that will most closely match the emotional demands of the words and music" (Miller, 1996: 28). However, despite his support for the inclusion of individual musicality, he warns teachers about students who might stray too far from their technique to portray emotion by stating that expression and musical nuance should be achieved without "violating the efficient function of the instrument" (Miller, 1996: 35, 102). Miller also regards facial and body language as "essential" to a performance, and encourages instructors to help their students learn the language of gesture (Miller, 1996: 150). Based on these statements, it seems that Miller acknowledges that expression during a performance is almost as important as the singing voice (Miller, 1996). He even recognizes the challenges an instructor might face when trying to teach expression due to the "mystery" of an imaginative performance (Miller, 1996). However, his anatomically focused pedagogy on its own does not 
easily allow for teachers to assist students in developing an in-depth understanding of "sensed emotion within the confines of an art form" (Miller, 1996: 150). With this in mind, a closer look at the literature surrounding communication accommodation theory will explore how this interdisciplinary theory can be applied to Miller's vocal pedagogy.

\section{0-Communication Accommodation Theory}

Communication accommodation is a large part of our society (Babel, 2009). In some cases, how an individual is socially perceived can be determined by how accommodating they are to an interlocutor (Babel, 2009). Communication accommodation theory (CAT) includes all elements of communication, such as pronunciation, gesture, body language, facial expression, etc. CAT recognizes the motivations underlying communication by focusing on the modification of an individual's communicative process to match or differ with a conversation partner (Coupland et al., 1991: 6). While accommodation is often a natural phenomenon within everyday conversations, Babel (2009) argues that the fluctuation in degree of accommodation indicates that a speaker consciously is employing the technique (24). To analyze how an individual is accommodating, CAT outlines two main components - divergence and convergence - that demonstrate the spectrum of accommodation. Meyerhoff (1998) describes an individual's use of accommodation as a means to invoke social identity in a community by accentuating the similarities of its members through communication convergence, and differentiating with nonmembers through divergence. Therefore, as an individual engages in daily communication, he or she constantly shifts between convergence and divergence (Coupland et al., 1991). Vocal lessons within a university setting are conducted one-on-one with the teacher and student, which is why CAT's focus on an individual's accommodation to a conversation partner helps identify the 
communicative acts present in a singing lesson. As forms of communication, speech and singing have similarities that allow CAT to successfully explore vocal instruction. Learning tools such as modeling and intentional convergence and divergence are present in both disciplines, and a deeper understanding of how these learning tools function can enhance vocal instruction.

\section{1-Divergence}

The use of divergence in communication settings often involves the "emphasizing or increasing of dissimilarities between styles" (Coupland \& Giles, 1988). Some scholars suggest that when divergence occurs it can cause miscommunication; however, Williams (1999) indicates that it is often "missed strategies" of under or over accommodation. The literature suggests that, in many cases, divergence is used as a tool to maintain a sense of individual identity in communication style (Boylan, 2009), which indicates that divergence and convergence can be consciously employed (Babel, 2009). Coupland and Giles (1988) define the differences between conscious and subconscious events as accommodative shifts and normative shifts. The latter represents a conscious event, and because the focus of this research is to understand and employ accommodation techniques in a vocal lesson setting, more attention will be given to normative shifts. A normative shift carries with it the "complexities" of communication such as motivation (Coupland \& Giles, 1988: 179-180), which is important for understanding how an individual can use accommodation as a tool. Recognizing a communicator's decision to employ divergence to maintain his or her individual communicative style is useful when analyzing the accommodative strategies available to instructors teaching vocal music at the university level. The use of divergence during a lesson provides a means for an instructor to encourage an individualized understanding of expressive acts. 


\section{2-Convergence}

If divergence is used as a tool for differentiating with interlocutors, convergence is used to accentuate, and in some cases increase, the similarities between conversation partners (Meyerhoff, 1991). Convergence is the most common accommodation tool used by communicators, which is due to an individual's desire or need to demonstrate similarities with the style of an interlocutor (Prince, 1988). In many cases, communicators associate convergence with a shared identity and a positive relationship (Boylan, 2009), which has led to the majority of the research surrounding CAT to be focused on convergence. Some researchers have dissected the act of convergence into smaller stages to better understand the complexities of this accommodation technique.

Boylan (2009) devised a two-tier method, which is divided into (1) convergence of expression and (2) convergence of intentionality. Analyzing convergence tactics with this method can help to uncover the psychological depth of the action (Boylan, 2009). Boylan (2009) describes convergence of expression as "mimicry," which suggests that the communicator is using convergence as a temporary method to convey similarities (287). Mimicry is a common technique in vocal lessons to teach technical components such as vowel placements, vibrato, and breath support. Convergence of intentionality suggests that the recipient understands and agrees with the communication method of the sender (Boylan, 2009). As an example, convergence of intentionality in a vocal lesson takes place when a student fully understands the action and agrees with an instructor's opinion on proper singing posture, which indicates that the student has moved past the mimicry stage and understands the concept enough to apply it in a different setting or scenario. Techniques such as selecting an accommodation model and mimicry can be 
used to achieve the ultimate goal of convergence of intentionality. Applying Boylan's (2009) two-tier method to the analysis of vocal pedagogy will allow for a closer analysis of possible convergence tactics that can be employed by an instructor.

Providing further insight into convergence strategies, Coupland et al. (1988) discuss a term similar to Boylan's (2009) convergence intentionality. In what they have defined as ideological accommodation, Coupland et al. (1988) suggest that when an individual feels that he or she must display adherence to the same "contents" of a group, they will select specific words or actions to match the style of communication used by a group. Ideological accommodation often includes the selection of a "communication prototype" that will guide the style choices of the converging individual (Coupland \& Giles, 1988: 181). An illustration would be a teacher using the example of an upper year student to demonstrate an ideal method of singing. With this communication prototype selected, a student has a visual and audible idea of what they are aiming to achieve. This selection of a communication prototype is also discussed in Prince's (1988) research, but is alternatively referred to as an accommodation model (315). The selection of an accommodation model once again supports the idea that an individual can use intentional accommodative shifts to alter their communication style towards a selected model. The extent of the accommodation tactics will determine the complexity of the accommodative shift, and, with further research, could point to the intentions behind the decision to converge. These subcategories of convergence serve as important references when analyzing the pedagogical approach of vocal lessons in Ontario Universities.

\section{3 - CAT and Second Language Acquisition}


Communication accommodation is a frequently cited source in non-native language studies. Zuengler (1991) considers CAT "a sound and potentially useful theory for second language variation, particularly in its ability to explain differences in acquisition" (224). In an attempt to grasp a non-native language, learners use convergence tactics to demonstrate understanding and relate this understanding to their teachers (the accommodation model) (Zuengler, 1991). Zuengler (1991) also states that even if linguistic convergence is not immediately possible — due to a factor such as an accent—psychological convergence is employed (225). In the initial stages of learning a second language, beginners are not likely to demonstrate divergence, unless they feel they are under an "ethnic threat" (Zuengler, 1991, 227). Music - particularly expression, which deals with the language of the body — can be considered a second language. Therefore, the information surrounding second language acquisition is relatable to the study of music.

\section{4-CAT and Richard Miller}

Throughout his pedagogical documents, Miller describes methods of teaching that align with the strategies of CAT. The most obvious example is the use of modeling or mimicry. He states, "modeling plays an important role in the teaching of any instrument" (Miller, 1996: 28). Miller claims that a teacher that is able to produce a "variety of sounds in his or her own voice will be best equipped to guide the student to timbres that are right," suggesting the use of modeling as a teaching tool (Miller, 1996: 28). As an act of convergence, modeling is a technique that involves a student accommodating a teacher.

Previous studies have already identified the success of CAT in an educational setting. Prince (1988) identifies a Russian-Jewish folk singer's use of accommodation models to increase 
the accuracy of her Yiddish pronunciation. Similarly, in a study surrounding classroom culture, researchers witnessed how accommodation tactics allow a professor and a student to "develop a widening repertoire of instructional and relational communication practices," ultimately increasing the probability of a positive learning outcome (Crabtree \& Sapp, 2004: 121). These studies demonstrate how accommodation tactics can work to ensure that both student and teacher have a shared understanding of the concepts being taught. This idea is demonstrated in Miller's pedagogy when he insists that voice students must be provided with a foundational understanding to learn how to sing.

In On the art of singing, Miller suggests that a teacher should "explore the technical routes available for the externalization of internal emotion" (Miller, 1996: 150). However, he does not specifically mention the details of these technical routes. This statement highlights the lack of practical techniques in Miller's pedagogy for instructors looking to teach expression, and leads to the formation of the research question guiding this study. 


\section{RESEARCH QUESTION}

The research question framing this study aims to bridge the gap present in the current literature regarding the instruction of expression. Drawing from both communication and music education perspectives, the goal of this study is to investigate the similarities of the two disciplines to enhance the instruction of the aesthetic properties of voice performance, such as expression. Therefore the research question guiding this MRP is:

1. Could communication accommodation theory enhance the current authoritative pedagogy for vocal instruction by offering perspectives on the communicative acts that occur during a vocal lesson to help instructors convey to students the meaning and understanding of expression?

Based on this research question, this MRP examines the applicability of communication accommodation theory to the one-on-one teaching environment of vocal instruction at the university level as outlined by Miller's authoritative pedagogy on the teaching of expression. 


\section{METHODOLOGY}

To determine the intersections between communication accommodation theory and music education, this study analyzes the syntax related to the teaching of expression from two of Miller's influential publications on vocal pedagogy. To contextualize the dataset, a qualitative research approach was employed for the data collection and analysis. The collection and analysis occurred over two phases: 1) a thematic analysis of the two pedagogical documents to uncover discussions of expression, and 2) an intention analysis to determine the pedagogical interpretation of the expression excerpts.

For the first phase, a thematic analysis was used to identify the statements related to artistic expression from Miller's two pedagogical texts. This thematic analysis comprised of reading the texts and extrapolating sentences that broached the topic of expression. This was then followed by an intention analysis, which focused on studying the expression discussions for their pedagogical value in terms of their capacity to provide teachers with strategies to convey to a student how to achieve musical expression. Intention analysis is a method of categorization that aims to display the function of sentences (Carlos \& Yalamanchi, 2012). It is often used in marketing or business related contexts to help determine consumer intentions such as, criticism, comparison, purchase, etc. (Carlos \& Yalamanchi, 2012: 2). Carlos and Yalamanchi (2012) posit that recognition of the communication intentions relevant to the situation (i.e. sales, marketing, and customer service) can help improve understanding and increase the function of the communication. From this perspective, the use of intention analysis in this study will provide a better understanding of the intention categories as applied to Miller's pedagogical writings and how they can increase the function of expression instruction. Intention analysis used within this 
study helped to identify the similarities in the quality or meaning of the collected excerpts, and their categorization into more specific categories under the theme of expression.

The specific methodology employed was as follows. First, the texts were read for statements related to achieving artistic expression. These excerpts were then extrapolated and placed in a table in the order that the statements appeared in each text. Once the initial collection of data was complete, the sentences were checked individually to ensure that they focused on the discussion of musical expression. Sentences that were did not fit this criterion were removed from the dataset. Phase two involved determining the intention behind each excerpt in the dataset. This was done inductively by reviewing the excerpts; patterns or similarities between the extrapolated sentences and recognized intention patterns (i.e. question, example, warning, etc.) were identified at this stage in the process. With the identified intention categories formulated, the data was reviewed again to place each individual excerpt under an intention category. This step was repeated for accuracy.

\section{Sources for Analysis}

The data for this study was derived from two vocal pedagogical texts written by Richard Miller. As outlined in the literature review, Miller is considered an influential figure in the modernization of vocal pedagogy. Voice instructors teaching at the university level in Ontario consistently refer to his texts as authoritative resources to learn how to sing. ${ }^{1}$ In addition to the endorsement of Miller's texts by vocal instructors, the voice syllabus for the Royal Conservatory of Music (RCM) cites all of Miller's texts in the recommended readings for RCM teachers

\footnotetext{
${ }^{1}$ Syllabi from University studio courses (individual lessons) provide supplementary texts for voice students. Using Western University's Don Wright Faculty of Music as an example, the online syllabi from both the Gassi and Chiles studio list all of Miller's pedagogical texts as important readings for the course (Gassi, 2014; Chiles, 2014). Similarly, the Royal Conservatory lists five of Miller's pedagogical texts as suggested readings for vocal teachers (The Royal Conservatory of Music, 2012).
} 
(Royal Conservatory of Music, 2012). The extensive inclusion of Miller in the RCM syllabus is significant because the RCM's grading system influences the application requirements for music programs at Ontario universities. For example, students are expected to perform at the grade eight level of the RCM program upon entering their first year of university vocal studies

(“Audition information for voice," Western University, n.d.). This connection suggests that many of the highly qualified vocal teachers (i.e. registered RCM teachers and university instructors) use techniques from the pedagogy listed in the RCM voice syllabus.

When selecting the two documents for this study, consideration was given to the focus of each of Miller's publications. His published work is either voice type specific (i.e. soprano, tenor, mezzo-soprano, and bass) or generic. To date, Miller has published seven pedagogical texts (from 1986 to 2008). Two of these texts were too specific for this study; one deals only with the pedagogy surrounding a single genre of classical vocal music, and the other is composed in a question and answer format. The question and answer style document was written to address questions Miller had received from singers and teachers during his research and thereforeunlike the two texts selected for this study — did not incorporate all areas of vocal pedagogy. With the remaining texts the goal was to select one text that focused only on one voice type and another text that focused on the voice as a whole. The rationale for this decision was to support the dataset with a well-rounded view, incorporating Miller's two main styles of pedagogical writing — combined voice types and voice type specific. Training soprano voices (2000) was chosen to represent the voice type specific classification, and On the art of singing (1996) was selected to provide a generalized approach to vocal pedagogy.

\section{On the art of singing, 1996}


In this comprehensive text, Miller provides information that covers the full spectrum of teaching voice. He states that his text traverses all aspects of vocal pedagogy, including "musicianship, style and interpretation, career preparation and development, efficient vocal function and vocal health," (Miller, 1996: $x v$ ), formulated from his research as a performer and teacher. Recognizing the lack of accessibility of vocal science studies and diverse pedagogy, Miller created this document as a resource to make vocal pedagogy "more accessible" (Miller, $1996 ; x v)$.

Training soprano voices, 2000

While this source is based on the same pedagogical foundation as in On the art of singing (1996), Training soprano voices only focuses on the training of the soprano voice. Miller explains that "variations in pedagogic application" are necessary for training different voice types (Miller, 2000,17). This text provides "practical technical exercises" dealing with the "performance literatures of the soprano" (Miller, 2000: 16).

\section{Data Collection and Thematic Analysis: Phase I}

The literature review indicates that the information available to vocal teachers for teaching expression is limited. By uncovering how frequently or infrequently expression is discussed in Miller's two pedagogical documents, this study is able to determine whether or not this gap in the literature is supported by the dataset. To successfully collect excerpts from the two pedagogical texts, deductive codes were established. A deductive approach was taken to ensure that the collected excerpts fit under the theme of expression. The determined codes are based on the terminology used in the music community to indicate the act of expression. An 
article by musician and researcher John Dilworth (2004) provided the foundation for the creation of the thematic analysis codes as the terminology he uses to explain the act of expression in music was useful in the data collection. Dilworth (2004) states that there is ambiguity surrounding the concept of expression-which incorporates components such as emotion, creative intention, artistry, and interpretation (1-2). To compile a well-rounded collection of expression discussions, some of the selected codes are synonyms for the term expression as used in a musical setting. The following table lists and defines these codes that were derived from Dilworth's paper.

\begin{tabular}{|l|l|}
\hline \multicolumn{2}{|c|}{ TABLE I: Thematic Analysis Code Descriptions } \\
\hline Code & Definition \\
\hline $\begin{array}{l}\text { Expression } \\
\text { Includes: express, expressive, expressed }\end{array}$ & $\begin{array}{l}\text { The deliberate act of conveying an internal } \\
\text { state of feeling through vocal and/or } \\
\text { physical acts (Ekman, 1997). }\end{array}$ \\
\hline $\begin{array}{l}\text { Emotion } \\
\text { Includes: emotional, emotionally, emotive }\end{array}$ & $\begin{array}{l}\text { A mental state of feeling or affection } \\
\text { (Oxford English Dictionary, 1987). }\end{array}$ \\
\hline Intention & $\begin{array}{l}\text { The attempt to project a specific feeling } \\
\text { whether or not they match the performers } \\
\text { internal state (Adachi \& Trehub, 2000). }\end{array}$ \\
\hline Artistic & $\begin{array}{l}\text { Involving the application of musical } \\
\text { nuance and creativity (technical and } \\
\text { affective) to a musical performance } \\
\text { (Edidin, 2000). }\end{array}$ \\
\hline Interpretation & $\begin{array}{l}\text { The way in which a performer understands } \\
\text { and portrays the emotional cues of a } \\
\text { composition (Silverman, 2008). }\end{array}$ \\
\hline
\end{tabular}


Phase I of the methodology involved scanning the texts for references that matched the determined codes. In this first phase of the data collection, if the code word was listed within a phrase in the pedagogical text, it was included in the dataset. The collected excerpts were copied into a document in chronological order by the page number of their location in each document. Initially, 91 excerpts were collected; however after a re-evaluation five of the excerpts were determined to be inconsequential and were removed from the dataset, leaving a total of 86 excerpts. The rationale for the removal of excerpts from the dataset was that the excerpt did not directly deal with the topic of expression. Of these 86 passages, 26 were collected from Training soprano voices (2000), and 60 were collected from On the art of singing (1996). This difference in excerpts collected from each document is not surprising due to the contrast in book lengths; Training soprano voices has 196 pages, while On the art of singing has 316.

Of the five thematic code categories, Expression and Emotion had the largest number of citations. Artistic comprised a quarter of the dataset, while Interpretation only was mentioned in a few samples. There were no relevant samples for the Intention code. Table 4 displays the collected data by code.

\begin{tabular}{|l|r|r|}
\hline \multicolumn{4}{|c|}{ Table 2: Data Collected per Code } \\
\hline Code & Total Excerpts & Percentage \\
\hline Expression & 34 & $40 \%$ \\
\hline Emotion & 27 & $31 \%$ \\
\hline Artistic & 22 & $26 \%$ \\
\hline Interpretation & 3 & $3 \%$ \\
\hline Intention & 0 & $0 \%$ \\
\hline
\end{tabular}




\section{Intention Analysis: Phase II}

The second phase of the analysis involved categorizing the data based on the intention of the statement in relation to the pedagogical information it conveys. By analyzing the intention Miller places behind each extrapolated statement, it was possible to determine how he approaches the overall discussion of expression within his pedagogy. Each of the 86 collected excerpts was examined to determine what kind of purpose they served in the document. The categories for the intention analysis were determined inductively; the evidence in the dataset determined the coding categories.

As frequent categories began emerging from the data, it became apparent that the intention codes fell under two larger themes: Instructive and Non-instructive (See Table 3). For example, the intention category Example (See Table 4) falls under the larger category of Instructive, while the intention category of Warning falls under the larger category of NonInstructive.

\begin{tabular}{|l|l|l|l|}
\hline \multicolumn{4}{|c|}{ Table 3: Overarching Intention Themes } \\
\hline Theme & Definition & Includes & Example \\
\hline \multirow{5}{*}{ Instructive } & $\begin{array}{l}\text { Miller's intention is to } \\
\text { provide the reader with } \\
\text { either an example or } \\
\text { method for achieving the } \\
\text { desired expressive } \\
\text { outcome. }\end{array}$ & $\begin{array}{l}\text { Categories: } \\
\text { Example } \\
\text { Educative }\end{array}$ & $\begin{array}{l}\text { "Caro nome' } \\
\text { romantic ecstasy through } \\
\text { sequential [vocal] } \\
\text { onsets" (Miller, 2000: } \\
\text { 64). }\end{array}$ \\
\hline $\begin{array}{l}\text { Non- } \\
\text { instructive }\end{array}$ & $\begin{array}{l}\text { Miller's intention is to } \\
\text { discuss concepts } \\
\text { concerning expression } \\
\text { without referring to direct } \\
\text { examples or methods for } \\
\text { achieving the desired } \\
\text { outcome. }\end{array}$ & $\begin{array}{l}\text { Categories: } \\
\text { Wuestion } \\
\text { Explanatory }\end{array}$ & $\begin{array}{l}\text { "Vocal colouration that } \\
\text { produces ugly sound is } \\
\text { neither musical not } \\
\text { expressive" (Miller, } \\
\text { 1996: 180). }\end{array}$ \\
\hline
\end{tabular}

From these two overarching themes, five intention categories emerged from the analysis. Table 4 
below outlines these categories.

\begin{tabular}{|c|c|c|}
\hline \multicolumn{3}{|c|}{ Table 4: Intention Categories } \\
\hline Category & Definition & Example \\
\hline Example & $\begin{array}{l}\text { Referring the reader to an } \\
\text { illustration or external } \\
\text { resource. }\end{array}$ & $\begin{array}{l}\text { "For purposes of heightened } \\
\text { expression, as in Als Luise } \\
\text { die Brife ihres ungetreuen } \\
\text { Liebhabers verbrannte," } \\
\text { Mozart depends on brief, } \\
\text { detached onsets" (Miller: } \\
\text { 2000: 62-63). }\end{array}$ \\
\hline Warning & $\begin{array}{l}\text { Providing the reader with a } \\
\text { worst-case scenario should } \\
\text { the pedagogy be ignored. }\end{array}$ & $\begin{array}{l}\text { "Unless the technical } \\
\text { problems of the singing } \\
\text { instrument are solved, a } \\
\text { singer cannot be an } \\
\text { expressive artist" (Miller, } \\
\text { 2000: 172). }\end{array}$ \\
\hline Question & $\begin{array}{l}\text { Posing questions (including } \\
\text { rhetorical). }\end{array}$ & $\begin{array}{l}\text { "With respect to } \\
\text { performance } \\
\text { communication, the } \\
\text { ultimate question comes } \\
\text { down to how one unites } \\
\text { technical skill with artistic } \\
\text { expression" (Miller, 2000: } \\
174 \text { ) }\end{array}$ \\
\hline Educative & $\begin{array}{l}\text { Providing enough detail to } \\
\text { assist teachers in structuring } \\
\text { a teaching technique. }\end{array}$ & $\begin{array}{l}\text { "Physical movement, and } \\
\text { the equally important ability } \\
\text { to achieve physical } \\
\text { quietude, play important } \\
\text { roles in releasing the body } \\
\text { and voice for emotive } \\
\text { expression" (Miller, 1996: } \\
\text { 150). }\end{array}$ \\
\hline Explanatory & $\begin{array}{l}\text { Offering an opinion with a } \\
\text { lack of detail and does not } \\
\text { assist in forming teaching } \\
\text { techniques. }\end{array}$ & $\begin{array}{l}\text { "Singers feel the need to } \\
\text { communicate emotions and } \\
\text { to express dramatic and } \\
\text { musical ideas through vocal } \\
\text { sound" (Miller, 1996: 62). }\end{array}$ \\
\hline
\end{tabular}

Example Category 
The Example category identifies an excerpt that references an external source or provides a relevant illustration to explain a point. The Example category is important because it is a method used by Miller to increase understanding of the discussion on musical expression. Miller offers statements that fall under the Example category to clarify the meaning of expression by providing a reference to a detailed or familiar source. These detailed and familiar statements represent examples such as a clip of sheet music from a well-known opera or a title of a piece of classical vocal repertoire that the teacher can refer to externally. The Example excerpts are instructional and provide teachers with an effective visual cue or musical clip that can help them convey that knowledge to their students. In excerpts $4 a$, $5 a$, and $6 a$ (see Appendix A), Miller refers to well-known vocal pieces to support his expression discussion, suggesting a method of demonstration through the written text. Using an example helps convey an idea, and therefore works well to assist vocal instructors in understanding and teaching musical expression to their students.

\section{Warning Category}

The Warning category features excerpts that strive to encourage the adoption of the pedagogical statement by warning the reader that neglecting to follow the advice in the statement may result in a poor or unsuccessful outcome. With respect to achieving artistic expression, Miller claims that a performance will not be successful if his advice is ignored. These Warning statements are found in excerpts such as $13 a, 14 a, 19 a, 28 b, 32 b$, and 34b. Miller also warns against the potential of vocal injury if a proper approach to expression is not taken, which is exemplified in excerpts $18 a, 56 b$, and $57 b$. The Warning excerpts attempt to invoke action by presenting a worst case scenario, and can be perceived as presenting "scare-tactics" to incite 
adherence to Miller's pedagogical approach. The Warning excerpts are not always instructional, as $18 a, 13 b$, and $44 b$ demonstrate, but are blunt statements meant to highlight important considerations for music expression instruction.

\section{Question Category}

The Question category includes excerpts that pose a rhetorical or non-rhetorical question. This type of excerpt prompts the reader to think about the query posed regarding the pedagogy on musical expression. The Question excerpt is significant because it demonstrates a discussion that is not instructional, providing the instructor with no pedagogical method to assist in teaching the topic; rather, the objective is to have the reader consider his or her own response to the question. As demonstrated in excerpts $20 a$ and $2 b$, Miller's use of the question form elicits consideration from the reader regarding the inquiry into expression, but does not provide any practical technique for achieving this goal.

\section{Educative Category}

The Educative category presents excerpts that provide teachers with practical information or techniques to impart on students to help them achieve an expressive outcome. The Educative category is important because the excerpts that fall under this category provide instructors with guidance and detailed instructions that help them teach expression. Miller uses the statements that fall under Educative category to assist teachers with the instruction of expression. This is exemplified in excerpts $2 a, 9 a, 5 b, 6 b, 30 b, 33 b$, and $45 b$. In these sentences, Miller outlines a methodological process for achieving musical expression. Examples 12a, 17b, 18b, and $21 b$ are 
also instructive because they provide the reader with the teaching applications and terminology necessary for coaching a vocal student towards expressive singing.

\section{Explanatory Category}

The Explanatory category contains excerpts that describe components of expression from Miller's perspective. This category is significant since it provides readers with knowledge on musical expression, and provides insight into how this expression works within the voice. In excerpts $1 a, 14 b, 15 b, 16 b, 22 b, 50 b$, and $52 b$ Miller describes the elements that comprise good vocal expression. He does not provide any technique or methodology to achieve this ideal state of expression; however, he alludes to the importance of expression in performance through the informative quality of the Explanatory excerpts. Other statements that fall under this category are excerpts $22 a, 3 b, 9 b, 23 b, 35 b$, and $60 b$, where Miller discusses the importance of good vocal expression, but does not go into detail regarding the process of instructing students on this topic. The statements that fall under the Explanatory category demonstrate Miller's perspective on expression as it relates to his form of pedagogy; however, the primary focus of these excerpts appears to be acknowledging the importance of expression in performance without providing a clear methodology for teaching expression.

Of these categories, the majority of the excerpts fell under Educative and Explanatory (See Table 5), which shows that Miller provided an almost an equal amount emphasis on Instructive and Non-instructive discussions regarding expression. Smaller percentages of the excerpts fell within the categories of Example, Question, and Warning. The following table displays the total number of excerpts for each category: 


\begin{tabular}{|l|r|r|}
\hline \multicolumn{5}{|c|}{ Table 5: Collected Data by Code } \\
\hline Category & Total Excerpts & Percentage \\
\hline Example & 3 & $3 \%$ \\
\hline Warning & 16 & $19 \%$ \\
\hline Question & 2 & $2 \%$ \\
\hline Educative & 32 & $37 \%$ \\
\hline Explanatory & 33 & $38 \%$ \\
\hline
\end{tabular}




\section{FINDINGS AND DISCUSSION}

The focus of this investigation will now address the applicability of communication accommodation theory to the five different categories of intention. The communication acts used by Miller within his pedagogical approach—such as modeling and convergence and divergence - are explored and the connections between CAT and vocal instruction demonstrate the ways in which communication accommodation could enhance Miller's pedagogy concerning the instruction of expression.

\section{Miller's Approach to Expression}

Overall, Miller's discussion on expression is useful for vocal teachers. However, while some of the literature suggests expression is an ineffable quality of music, experienced by both the listener and performer, Miller prefers a pragmatic approach, considering expression as another technical component of singing, rather than an area of enjoyment or emotional catharsis (Miller, 1996: 149). It is the singer's job to successfully convey the emotional message of the composition to their audience through vocal, bodily, and facial communication.

\section{Main Themes}

When analyzing the dataset for sentence intentions, there was a difference in the amount of each intention category collected between the two pedagogical documents. The two documents were compared by calculating the percentage of each category in comparison to the number of excerpts collected from each source. In comparing the two sources, similarities were seen in the amount of excerpts from the Warning, Question, and Educative categories, while there was a large difference between the amount of excerpts from the Example and Explanatory 
categories. The two following tables demonstrate the number of excerpts divided by intention category per source.

\begin{tabular}{|c|c|c|}
\hline \multicolumn{3}{|c|}{ Table 6: Intention Category per source } \\
\hline & Source: $O n$ the art of singing & \\
\hline Category & Total Excerpts & Percentage \\
\hline Example & 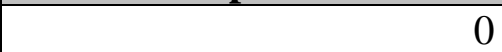 & $0 \%$ \\
\hline Warning & 11 & $19 \%$ \\
\hline Question & 1 & $2 \%$ \\
\hline Educative & 22 & $37 \%$ \\
\hline Explanatory & 26 & $41 \%$ \\
\hline
\end{tabular}

\begin{tabular}{|c|c|c|}
\hline \multicolumn{3}{|c|}{ Table 7: Intention Category per source } \\
\hline & ource: Training soprano voice & \\
\hline Category & Total Excerpts & Percentage \\
\hline Example & 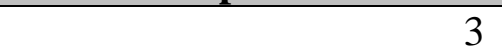 & $12 \%$ \\
\hline Warning & 5 & $19 \%$ \\
\hline Question & 1 & $4 \%$ \\
\hline Educative & 10 & $38 \%$ \\
\hline Explanatory & 7 & $27 \%$ \\
\hline
\end{tabular}

These percentages demonstrate a consistent number of categorized excerpts for the Warning, Question and Educative intentions in each source. However, there is a significant difference between the Example and Explanatory categories in the two sources. The analysis of the dataset shows that this is due to the nature of the two documents. Training soprano voices (2000) is written for instruction of a single voice type, and the Example category works well with the specificity of the document. On the art of singing (1996) is a more general pedagogical document including information relevant to all four-voice types, which makes using an example difficult in some cases. Oppositely, the larger percentage of the Explanatory category-in which the excerpts are not detailed (found in On the art of singing) - is due to the fact that the 
document is not directed to a specific voice type. To further contextualize the data, I will discuss now my interpretation of the intention analysis for each individual category.

\section{Example}

There were fewer Examples present within the collected excerpts than originally anticipated. As a useful method for conveying an idea, it was expected that Miller would frequently refer to specific musical works or illustrations of musical passages to help demonstrate his pedagogic strategies. However, the Example category was only present a total of three times within the data.

The Example excerpts presented were used only in Training soprano voices (2000), and referred to outside sources. The inclusion of outside sources provides support for Miller's pedagogical standpoint and substantiates his ideas within a larger context. This type of is demonstrated in sentence 5a: "Caro nome (Rigoletto), expresses romantic ecstasy through sequential onsets" (Miller, 2000: 64). (See also: Appendix 4a).

\section{Warning}

The Warning intention was an unexpected category. Often written with a negative undertone, the Warning excerpts represent an extended version of the Explanatory intention. This category also exposed Miller's biases on the subject of vocal pedagogy, often citing worse case scenarios should his suggestions be ignored. This scare-tactic is exemplified in excerpt 19a: "the [singer] who becomes so emotionally involved that they are unable to sing fail themselves, the composer, and the drama" (Miller, 2000: 174). (See also: Appendix $13 a, 28 b$, and 57b). 


\section{Question}

The Question intention category represents Miller's desire to encourage individual pedagogical thinking in the vocal teacher. The Question excerpts effectively provoke the reader to pause and contemplate the problem or concept raised by Miller. There were only two Question excerpts found within the dataset, but together they address Miller's main concerns regarding the instruction of expression. These overarching concerns — which Miller addresses through questioning — is demonstrated in excerpt $2 b$ : "The mystery of the performance art remains: How does the artistic imagination make use of technical skill to communicate beautiful sound and emotion?" (Miller 1996: 7). (See also: Appendix 21a).

\section{Educative}

While the Educative category was the most detailed out of all the recognized intentions, many of the excerpts within this category do not include specific techniques for teaching expression. The lack of specificity suggests that Miller is not as willing to state systematic methods for teaching expression as he is for other—more technical—components of the voice, which is perhaps due to the ineffectiveness of the "investigative study" and "mysterious nature" of expression (Miller, 1996: 71). The Educative excerpts and their detailed descriptions of pedagogical tactics is exemplified in phrase $5 b:$ "The teacher/performer who can similarly produce a variety of sounds in his or her own voice, and who is able to sort them out as to efficiency of production and effectiveness of expression, will be best equipped to guide the student to timbres that are right" (Miller, 1996: 28). (See also, Appendix 2a, 8a, 12a, and 17b).

\section{Explanatory}


This category included less detail than the Educative intention. However, these excerpts were necessary for furthering Miller's discussion of expression. While these passages provide teachers with an opportunity to better understand Miller's approach to expression in his own practice, they may find it difficult to determine how to instruct a student on expression due to the lack of detail present in these excerpts. These excerpts are informative; however, the lack of pedagogical technique provided can be seen in excerpt $25 a$ : "The artistic imagination is liberated to express itself only when freedom has been ingrained within the performance instrument itself" (Miller, 2000: 175). (See also, 22a, 1b, and 14b). With Miller's perspective of artistic singing in mind, I will now discuss the components of CAT that can be identified within or added to Miller's pedagogical approach to expression.

\section{Modeling in Vocal Pedagogy}

Within the dataset, excerpt $5 b$ provides clear evidence of the accommodative strategy of modeling. The Educative excerpt, "[t] he teacher/performer who can similarly produce a variety of sounds in his or her own voice, and who is able to sort them out as to efficiency of production and effectiveness of expression, will be best equipped to guide the student” (Miller, 1996: 28), suggests the use of modeling to help train a developing singer. This technique is not new to the music lesson setting. However, the application of CAT may assist teachers in enhancing their current method of expressive modeling. As discussed within the literature review, modeling is a strategy of convergence - the act of increasing similarities with an interlocutor through accommodation. Currently, vocal teachers often use modeling to demonstrate aspects of performance such as vowel clarity, vibrato, and ornamentation. In On the art of singing, Miller suggests that a teacher should be able to demonstrate many different vocal timbres to students to 
assist them in emoting (Miller, 1996). This suggestion represents a way to begin using modeling as a tool to teach vocal expression, but could be expanded into other areas of vocal performance, such as body and facial language, to encapsulate all aspects of expressive singing. In the one-onone setting of a voice lesson, a technique such as modeling can be successful as a method for teaching expression.

Many vocal teachers posit that a student's inability to embody the emotion of a piece is due to a lack of real life experience. Miller rejects this belief by arguing that a student's ability to demonstrate expression depends on their technical foundation in singing, not their emotional experiences outside of the studio (Miller, 1996). Basing the idea of modeling on Miller's approach to expression would mean that a teacher could demonstrate the expressive sound, and through the process of technical repetition, the student would be able to properly convey the emotional sound. However, the technical foundation as described by Miller does not include the instruction of facial and body language, despite Miller's (1996) recognition of their importance to performers. To enhance the instruction of expression, vocal instructors can build on Miller's pedagogical approach to modeling expressivity by modeling aspects of facial and body language.

The process of modeling can also involve the selection of strategic accommodation models, as suggested by Coupland and Giles (1988). Throughout his pedagogy, the collected data suggests that Miller frequently uses Explanatory phrases to discuss expression. Phrases such as: "simultaneously sing and portray intense emotion" (Miller, 2000: 173), and "timbre displays of tragedy, intrigue, jealousy and revenge" (Miller, 2000: 25), can be enhanced with the inclusion of an accommodation model. For example, teachers can assign accommodation models (i.e. professional classical singers) for the specific components of expressive performing they are trying to teach their student. For a soprano singing the aria "O mio babbino caro," they might 
recommend watching a video recording of Renee Fleming for an example of successful facial expression; a video of Anna Netrebko for body language and gesture; and a sound recording of Montserrat Caballé for expressive vocal nuance. This extends Miller's suggestion of having the teacher demonstrate to students' different vocal sounds to achieve expression. By providing students with a variety of accommodation models of different backgrounds and vocal types, they can be sure that they are receiving a variation of proper methods for expression in music. It would be necessary for the student to understand what it is that he or she is looking for from each performance, and with the teacher's assistance some analysis of the performances can help ensure that an understanding of the expressive qualities has been achieved. The accommodation model could act as a visual and verbal guide for the student and with additional modeling and direction from the instructor, an in depth understanding of expressive singing is attainable.

The power of selecting strategic accommodation models is proven in Prince's (1988) study on the acquisition of a Yiddish accent by a Russian-Jewish folk singer Sarah Gorby. Due to the fact that Yiddish is not a native dialect to Gorby, she had to be selective in her convergence of accommodation models (315). By listening only to Yiddish speakers that she wanted to emulate, Gorby ensured that her acquisition of a Yiddish accent was accurate and appropriate for her use.

\section{CAT's Two-Tier Method}

Scholars have described modeling as a successful way to achieve accommodation; however, the challenge for a vocal teacher is to ensure that his or her strategic modeling is translating into an understanding of the practice and is not simply "mimicry." Boylan's (2009) two-tier method for accommodation is divided into convergence of expression and convergence 
of intentionality. Convergence of expression represents mimicry, while convergence of intentionality demonstrates a shared understanding of the accommodative action.

Applying this tiered approach to a vocal lesson may assist instructors in achieving Miller's ideal level of expression. As Miller (1996) explains in his discussion of expression, "[n]o singer can hope to exhibit artistry until the basic rules of the craft have been mastered" (187). Miller further states that musical expression is achieved through "proper linguistic flow, phrase movement, textual insight and stylistic security" (133). These components can be taught using the two-tier method of convergence outlined by CAT. A comparison of the acquisition of linguistic flow—an element of expression — to the acquisition of a spoken accent in everyday communication will describe how this tiered process works.

The first tier in Boylan's (2009) convergence method, the convergence of expression, determines if the learner can mimic the communication action of the teacher. In developing linguistic flow, a vocal instructor would vocally demonstrate the ideal phrase, which involves elements of vowel and consonant pronunciation, breath control, and legato (which involves smoothly connecting the sound of each word in the musical phrase together). Again, this process is similar to the study conducted by Prince (1988) on the folk singer Gorby. The singer mimicked the pronunciation of native Yiddish speakers to aid her in the initial learning process. As the first step in the accommodation process, convergence of expression (Tier 1) only involves mimicking the communication action of a desired interlocutor. Without proceeding to the convergence of understanding tier (Tier 2), it is likely that the student has only parroted back the sound of the teacher.

In the second tier—convergence of intentionality—understanding of the communicative act takes place. It is within this tier that the student can move beyond mimicry, and through 
increased awareness, he or she can independently reproduce the action. For convergence of intentionality to take place, the teacher must ensure that the vocal student understands all of the technical elements required to produce linguistic flow. Within his pedagogy, Miller (2000) states that this understanding can be achieved through "factual communication of information" (94). The teacher must use factual information to supplement the process of mimicry as the process continues. As an example, while a student is reflecting the action of legato singing, his or her instructor can inform him or her that this process will allow for better breath management, providing the student with more freedom for musical expression. It is only with an understanding of the action that students will be able to reproduce the outcome individually. This is exemplified in Prince's (1988) study; Gorby moves beyond the stage of mimicry when she begins to understand the syntactical properties of the Yiddish language. This was recognized in the study through a chronological examination of Gorby's folk recordings. Prince (1988) analyzed Gorby's delivery of the Yiddish language on each recording, and by cross-referencing the songs with the singer's personal notes and letters, he determined that Gorby had gathered an understanding of the language through the use of Yiddish speaking accommodation models.

An expression excerpt represented in the dataset states that "student and teacher must creatively share in analyzing and determining what remains lacking in technique and expression" (Miller, 1996: 181). Boylan's (2009) two-tier method provides vocal instructors and students following Miller's pedagogy an opportunity to measure the success of their modeling efforts. By evaluating students on the scale of convergence of expression to convergence of intentionality, vocal instructors can better confirm that understanding is taking place.

\section{Divergence as a Teaching Tool}


The data for this study reveals that Miller considers expression as achievable once a strong foundation in vocal technique has been set, and his use of Educative and Explanatory phrases reaffirm this notion. However, while many of the Educative excerpts provide detailed information on what is involved in developing an expressive performer, they do not offer concrete suggestions on how to assist a student in achieving expressive freedom.

The modeling technique previously discussed relies primarily on the act of convergence. For learning to take place, the student must conform to the instructor's ideas on how to accomplish expressive singing. This section of the discussion will examine how the act of divergence within communication accommodation theory can assist vocal teachers and students in achieving a natural and believable communication of musical expression. In the following three Explanatory excerpts, Miller alludes to the act of divergence:

Excerpt: "Throughout the song the singer should try several voice qualities before settling for any one of them; the emotion will thereby be greatly enhanced" (Miller, 2000: 162).

Excerpt: "The singer determines which [vocal] colours produce for her the most convincing interpretation" (Miller, 2000: 163).

Excerpt: "The singer determines which of these [vocal] colours produces the best aesthetic result and the most physical comfort" (Miller, 2000: 163).

Divergence can be used as a conscious tool to differentiate oneself from another (Babel, 2009). In this situation divergence can be used as a tool to encourage a student to develop his or her idiosyncratic method for achieving believable communication of expression. Miller (2000) 
suggests that a singer should determine what vocal colouration works best for them physically and emotionally. Teachers can encourage this process of self-recognition if they understand how CAT's divergence strategy works. A possible method for assisting a student in developing an individualized vocal expression is to encourage them to apply different emotions - through vocal nuance, facial and body language — to a piece of music. This supports Miller's suggestion in the first excerpt listed above. He posits that a singer must experiment with various vocal qualities before determining which one best suits the music and the performer (Miller, 2000).

In everyday communication, divergence is sometimes used as a way to maintain the uniqueness of one's communicative style. However, in an educational setting it can be argued that convergence is often seen as the appropriate technique, because an agreed understanding connotes learning. While convergence is a useful strategy, divergence provides developing vocalists with a way to individualize their learning experience and maintaining a sense of artistry, while, at the same time, learning the fundamentals. This idea relates to Miller's (1996) statement of the teacher and student "creatively sharing" in the process of determining what is missing in technique and musical expression (181). Similarly, Miller (1996) states in an Educational excerpt that "a [vocal] coach is not there to teach the singer music, but to help him or her find freedom of musical expression" (133). These statements suggest that a teacher must be willing to accept a student's desire to insert his or her unique method of expression into a piece of music. The use of divergence can help prepare students to take artistic liberty in their style of expression, encouraging them to rely on their knowledge of vocal technique. It should be mentioned, that the use of divergence might only be successful with higher-level students, who have a foundational understanding of vocal function. Divergence does not represent a 
disagreement with the teacher, rather it promotes a more instinctive and natural way to approach expression.

These findings demonstrate the possible success of teaching expression using communication accommodation strategies. Incorporating communication tactics like modeling, two-tier convergence, and divergence into a lesson will enhance Miller's existing pedagogy and assist in strengthening the artistic properties of a singer's performance. The unique one-on-one setting of a vocal lesson makes it possible for the discussed communication tactics to be employed successfully, and recognizing the similarities between everyday conversation and vocal instruction will assist teachers in best utilizing their lesson time. Using CAT to expand Miller's pedagogy could assist teachers in creating focused techniques for better articulating and nurturing expressive singers. 


\section{CONCLUSION}

The findings of this MRP reveal that there is a gap in the literature regarding the instruction of expression in vocal music. This is problematic when it comes to providing instructors with a methodology for teaching expressive musical qualities. Miller's pedagogy is efficient in providing teachers with background information regarding the instruction of expression; however, it lacks the detail needed to provide a systematic approach to achieving results, which is largely why there has been criticism of the scientific approach to vocal pedagogy.

The crossover between expression in music and expression in everyday communication is undeniable and current research is beginning to highlight the connection between these forms of communication. However, in both cases, the ineffable nature of expression makes it difficult to define and articulate in a lesson environment, creating a challenging area of instruction. The connection between everyday communication and singing led to the discovery of communication accommodation theory and its applicability to interdisciplinary research. The one-on-one style of a vocal lesson in Ontario Universities represents a unique learning setting that can be effectively analyzed using CAT.

A careful examination of Miller's two pedagogical texts confirmed the gap in the literature. It was determined that Miller was already employing latent strategies of CAT, and that a better understanding of these strategies with an understanding of CAT can enhance the teaching of expression. Accommodation tactics such as, convergence of expression and convergence of intentionality, divergence, and modeling were examined in detail and combined with the related excerpts from Miller's pedagogy to demonstrate the possibility of CAT in this context. Singing teachers who are aware of the connection between communication 
accommodation and the instruction of singing will be more empowered to provide guidance on how to achieve expression. This study demonstrates that a large portion of the information concerning expression present in Miller's pedagogy does not provide teaching strategies, making the overall discussion of the topic largely uninstructive.

Further research in this area may reveal further similarities between everyday communication and vocal music. It is only with continued research that the gap in the literature regarding the instruction of expression will be bridged. However, research is not limited to this focused area of music education. The overlap between speech and singing provide scholars of both communication and vocal backgrounds the opportunity to uncover how the acquisition of one discipline is represented or reflected in the other. 


\section{APPENDICES}

\section{Appendix A}

\section{Training soprano voices (2000)}

\begin{tabular}{|c|c|c|}
\hline $\begin{array}{l}\text { Appendix } \\
\text { Reference }\end{array}$ & (4. & $\begin{array}{l}\text { Page } \\
\text { Number } \\
\end{array}$ \\
\hline $1 a$ & $\begin{array}{l}\text { "timbre displays...colors associated with tragedy, intrigue, jealousy, revenge, } \\
\text { or outright evil intention." }\end{array}$ & 25 \\
\hline $2 a$ & $\begin{array}{l}\text { "skillful singing requires higher rates of breath energy than those of } \\
\text { speech...in meeting the demands for artistic singing, air emission should be } \\
\text { paced over longer periods of time and at different intensity levels that in } \\
\text { speech." }\end{array}$ & 50 \\
\hline $3 a$ & $\begin{array}{l}\text { "In the literature itself we find composers making use of interjected onsets for } \\
\text { both vocal display and emotion." }\end{array}$ & $61-62$ \\
\hline $4 a$ & $\begin{array}{l}\text { "For purposes of heightened expression, as in Als Luise die Brife ihres } \\
\text { ungetreuen Liebhabers verbrannte," Mozart also depends on brief, detached } \\
\text { onsets." }\end{array}$ & $62-63$ \\
\hline $5 a$ & $\begin{array}{l}\text { "Caro nome" (Rigoletto), expresses romantic ecstasy through sequential } \\
\text { onsets." }\end{array}$ & 64 \\
\hline $6 a$ & $\begin{array}{l}\text { "The brief interjectory silences found in the cited passages attest that major } \\
\text { composers understood how the technical maneuvers of voice production could } \\
\text { be put to use in the enhancement of dramatic expression." }\end{array}$ & $64-65$ \\
\hline $7 a$ & $\begin{array}{l}\text { "Twentieth-century composers have not lost interest in the potential for } \\
\text { musical and emotional expression through the disjunct phrase and the repeated } \\
\text { vocal onset." }\end{array}$ & $67-68$ \\
\hline $8 a$ & "expressive phrase sculpturing and pacing" & 135 \\
\hline $9 a$ & $\begin{array}{l}\text { "Throughout the song the singer should try several voice qualities before } \\
\text { settling for any one of them; the emotion will thereby be greatly enhanced." }\end{array}$ & 162 \\
\hline $10 a$ & $\begin{array}{l}\text { "the singer determines which [vocal] colours produce for her the most } \\
\text { convincing interpretation." }\end{array}$ & 163 \\
\hline $11 a$ & "for emotional and dramatic reasons...timbre changes are the consequence." & 164 \\
\hline $12 a$ & $\begin{array}{l}\text { "the messa di voce (a dynamic swell) in the singing voice is remarkably } \\
\text { expressive." }\end{array}$ & 168 \\
\hline $13 a$ & $\begin{array}{l}\text { "Unless the technical problems of the singing instrument are solved, a singer } \\
\text { cannot be an expressive artist, successfully responding with the beauty of } \\
\text { vocal tone to text, drama, and music." }\end{array}$ & 172 \\
\hline $14 a$ & $\begin{array}{l}\text { "The ultimate goal of performance preparation-artistic communication-is } \\
\text { possible only when vocal freedom has been established." }\end{array}$ & 172 \\
\hline $15 a$ & $\begin{array}{l}\text { "...simultaneously sing and portray intense passion without actually } \\
\text { experiencing it fully." }\end{array}$ & 173 \\
\hline $16 a$ & $\begin{array}{l}\text { "...experiencing the action of the role, not the actual deed...the singer remains } \\
\text { the vehicle for its expression, not its personal embodiment." }\end{array}$ & 173 \\
\hline $17 a$ & $\begin{array}{l}\text { "Art is the ability to portray reality through the comprehension (not the } \\
\text { experiencing) of all the emotions." }\end{array}$ & 173 \\
\hline $18 a$ & $\begin{array}{l}\text { "Problems may develop for a singer if in the hope of achieving believable } \\
\text { communication of the drama she is urged to submerge herself completely in } \\
\text { the emotion of the text." }\end{array}$ & 173 \\
\hline $19 a$ & $\begin{array}{l}\text { "the [singer] who becomes so emotionally involved that they are unable to } \\
\text { sing fail themselves, the composer, and the drama." }\end{array}$ & 174 \\
\hline $20 a$ & $\begin{array}{l}\text { "Such inadequacies result from mistaken concepts regarding truth in artistic } \\
\text { communication." }\end{array}$ & 174 \\
\hline $21 a$ & "With respect to performance communication, the ultimate question comes & 174 \\
\hline
\end{tabular}




\begin{tabular}{|l|l|l|}
\hline $22 a$ & $\begin{array}{l}\text { down to how one unites technical skill with artistic expression." } \\
\text { "The more efficient the technical skill, the greater the potential for artistic } \\
\text { expression." }\end{array}$ & 174 \\
\hline $23 a$ & $\begin{array}{l}\text { "One must first develop the appropriate technique...technique and } \\
\text { communication comprise the psychology of artistic performance." }\end{array}$ & 174 \\
\hline $24 a$ & $\begin{array}{l}\text { "Skill in singing is not the product of raw emotion. Skill results from the } \\
\text { programming of physical, acoustic, and controlled emotional responses into } \\
\text { one gestalt." }\end{array}$ & 175 \\
\hline $25 a$ & $\begin{array}{l}\text { "The artistic imagination is liberated to express itself only when freedom has } \\
\text { been ingrained within the performance instrument itself." }\end{array}$ & 175 \\
\hline $26 a$ & $\begin{array}{l}\text { "Systematically dealing in advance with the technical components of an } \\
\text { art...franchises the artist to operate in a world of imagination and inspiration." }\end{array}$ & 175 \\
\hline
\end{tabular}

On the art of singing (1996)

\begin{tabular}{|c|c|c|}
\hline $\begin{array}{l}\text { Appendix } \\
\text { Reference }\end{array}$ & Excerpt & $\begin{array}{l}\text { Page } \\
\text { Number }\end{array}$ \\
\hline $1 b$ & $\begin{array}{l}\text { "Singing is largely a subjective action. They [singers] recognize only a } \\
\text { pervasive attitude toward performance in which the imagination is freed for } \\
\text { artistic expression by motor actions that are consistently repeatable." }\end{array}$ & 1 \\
\hline $2 b$ & $\begin{array}{l}\text { "The mystery of the performance art remains: How does the artistic } \\
\text { imagination make use of technical skill to communicate beautiful sound and } \\
\text { emotion?" }\end{array}$ & 7 \\
\hline $3 b$ & $\begin{array}{l}\text { "When the artistic imagination is coupled with technical } \\
\text { mastery...communication with the audience will be direct and } \\
\text { unencumbered." }\end{array}$ & 23 \\
\hline $4 b$ & $\begin{array}{l}\text { "it will be the sound that is most efficiently produced and that matches most } \\
\text { closely the emotional demands of the word and music." }\end{array}$ & 28 \\
\hline $5 b$ & $\begin{array}{l}\text { "The teacher/performer who can similarly produce a variety of sounds in his } \\
\text { or her own voice, and who is able to sort them out as to efficiency of } \\
\text { production and effectiveness of expression, will be best equipped to guide the } \\
\text { student to timbres that are right for the student." }\end{array}$ & 28 \\
\hline $6 b$ & $\begin{array}{l}\text { "Vocal colouration is an important part of artistry. Artistic singing requires a } \\
\text { palette of varied colours of dynamically shifting lights and shadows. Yet the } \\
\text { essential thing for professional sound production is to first establish a uniform, } \\
\text { stabilized timbre of the voice throughout all registers, with a full complement } \\
\text { of spectral colour." }\end{array}$ & 36 \\
\hline $7 b$ & $\begin{array}{l}\text { "The next essential ingredient is to learn how far a singer may momentarily } \\
\text { depart from the stabilized timbre for purposes of expression and musical } \\
\text { nuance without violating the efficient function of the instrument." }\end{array}$ & 36 \\
\hline $8 b$ & $\begin{array}{l}\text { "The energy source for singing must be properly applied to the mixture of } \\
\text { talent, communication, and musicianship. Until the energy source and } \\
\text { phonation are unified in the singing instrument, artistic gloss is meaningless." }\end{array}$ & 55 \\
\hline $9 b$ & $\begin{array}{l}\text { "Singers feel the need to communicate emotions and to express dramatic and } \\
\text { musical ideas through vocal sound." }\end{array}$ & 62 \\
\hline $10 b$ & $\begin{array}{l}\text { "No amount of attention to the concerns of audience communication, dramatic } \\
\text { interpretation, linguistic exactitude and artistry and musicianship can mask the } \\
\text { faulty weave in the vocal instrument." }\end{array}$ & 65 \\
\hline $11 b$ & $\begin{array}{l}\text { "A good performance is not a chance coming together of artistic, physical, and } \\
\text { acoustic factors; it is the result of coordinating technical, musical, and } \\
\text { emotional elements in preparation for the tasks of performance." }\end{array}$ & 67 \\
\hline $12 b$ & $\begin{array}{l}\text { "No amount of investigative study can unveil the psychological mysteries that } \\
\text { lie behind the accomplishment of artistic communication." }\end{array}$ & 71 \\
\hline $13 b$ & 'It is not possible to be 'musical and expressive'... when the instrument has & 84 \\
\hline
\end{tabular}




\begin{tabular}{|c|c|c|}
\hline & $\begin{array}{l}\text { not been disciplined. Freedom in artistic communication is not a "natural' } \\
\text { attribute. It is the result of skill." }\end{array}$ & \\
\hline $14 b$ & $\begin{array}{l}\text { "Our energies as singers and as teachers of singing are sometimes spent on } \\
\text { peripheral considerations about the singing art instead of being centered on the } \\
\text { acquisition of technical skills that allow artistic communication." }\end{array}$ & 87 \\
\hline $15 b$ & $\begin{array}{l}\text { "Classical vocalism is based on freedom of production and on certain acoustic } \\
\text { properties of the singing voice associated with functional efficiency. These } \\
\text { techniques permit the singing voice to project easily and to express a full } \\
\text { range of colourations and emotions without injury." }\end{array}$ & 98 \\
\hline $16 b$ & $\begin{array}{l}\text { "The internal image of a singer's self must match the actual image they are } \\
\text { externally displaying. Because he has never seen himself perform, he falsely } \\
\text { assumes that he looks like what he feels." }\end{array}$ & 102 \\
\hline $17 b$ & $\begin{array}{l}\text { "Every singer should have access to video equipment to prepare for public } \\
\text { performance...Feeling and imagining are insufficient guarantees that the } \\
\text { physical responses of the body are properly conveying the intended emotions } \\
\text { to the public." }\end{array}$ & 103-104 \\
\hline $18 b$ & $\begin{array}{l}\text { "Visual feedback makes it possible for the singer to be rid of extraneous, } \\
\text { idiosyncratic, and superficial movement, and to avoid appearing self-indulgent } \\
\text { or awkward in interpretation and communication." }\end{array}$ & 104 \\
\hline $19 b$ & $\begin{array}{l}\text { "A singer must be able to monitor his external behaviour while performing, so } \\
\text { that it conveys to an audience, through both voice and body, the desired } \\
\text { artistic intention." }\end{array}$ & 104 \\
\hline $20 b$ & $\begin{array}{l}\text { "Expressive vocal sound is dependent on the well-functioning physical vocal } \\
\text { instrument as its medium." }\end{array}$ & 104 \\
\hline $21 b$ & $\begin{array}{l}\text { "Perhaps the most expressive vocal device is the legato, which permits } \\
\text { continuous sound that then can be sculpted into eloquent phrases." }\end{array}$ & 106 \\
\hline $22 b$ & $\begin{array}{l}\text { "Expressions need to be seen within their historical literary and musical } \\
\text { settings." }\end{array}$ & 107 \\
\hline $23 b$ & $\begin{array}{l}\text { "A singer presents musical and literary ideas spread out over longer periods of } \\
\text { time than does the speaker. This duration factor allows the elements of the } \\
\text { vocal and musical expression to exceed those of normal spoken } \\
\text { communication." }\end{array}$ & 108 \\
\hline $24 b$ & $\begin{array}{l}\text { "Above all, the singer should not confuse heavy syllabification with } \\
\text { expressive singing." }\end{array}$ & 109 \\
\hline $25 b$ & $\begin{array}{l}\text { "Art consists of the disciplining of reality for the portrayal of emotion without } \\
\text { succumbing to emotion." }\end{array}$ & 114 \\
\hline $26 b$ & $\begin{array}{l}\text { "Art is knowing how those [emotional] experiences would feel and how to } \\
\text { translate them into communicable representations." }\end{array}$ & 115 \\
\hline $27 b$ & $\begin{array}{l}\text { "The singers task is not to experience emotional highs in performance but to } \\
\text { transform sentiment through artistic means so successfully that the audience } \\
\text { can share with the performer in the portrayal." }\end{array}$ & 115 \\
\hline $28 b$ & $\begin{array}{l}\text { "Expressively torturing individual notes and syllables... resembles broken } \\
\text { strings of beads that are the detriment of both timbre consistency and honest } \\
\text { communication." }\end{array}$ & 120 \\
\hline $29 b$ & $\begin{array}{l}\text { "The sophisticated singer does not mistake personal emotional indulgence for } \\
\text { artistic communication." }\end{array}$ & 120 \\
\hline $30 b$ & $\begin{array}{l}\text { "There are times when, for expressive purposes, some interruption of legato is } \\
\text { desirable." }\end{array}$ & 120 \\
\hline $31 b$ & $\begin{array}{l}\text { "If the singer allows one sound to move directly into the next, that singer now } \\
\text { has the means for playing with expressive dynamic control ensuring both } \\
\text { vocal and artistic integrity." }\end{array}$ & 121 \\
\hline $32 b$ & $\begin{array}{l}\text { "Both recitalist and opera singer must avoid repeated body impulses that } \\
\text { negate the dramatic situation... which is thought to be expressive and } \\
\text { emotive." }\end{array}$ & 123 \\
\hline $33 b$ & "Rhythm is essential to artistic singing." & 123 \\
\hline
\end{tabular}




\begin{tabular}{|c|c|c|}
\hline $34 b$ & $\begin{array}{l}\text { "The singer brings new perspectives to already existent works of art, but has } \\
\text { no right to turn them into vehicles of self-aggrandizement. The singer who, in } \\
\text { order to enhance him/herself, changes the composer's work into something } \\
\text { never intended by that creative artist is a fraud, not an artist." }\end{array}$ & 125 \\
\hline $35 b$ & $\begin{array}{l}\text { "The aim of performance should never be to prove to the audience how artistic } \\
\text { one is but rather to communicate the essence of the music and the text to the } \\
\text { listener." }\end{array}$ & 125 \\
\hline $36 b$ & $\begin{array}{l}\text { "We know also that the re-creative singing artist (singing works composed by } \\
\text { someone else) must depict emotion, word, and musical idea while submitting } \\
\text { to the constraints of the musical idiom, the poetry, the accompanying } \\
\text { instrument and even ambient performance circumstances." }\end{array}$ & 125 \\
\hline $37 b$ & "Style and artistry should not rob one of good vocalism." & 126 \\
\hline $38 b$ & $\begin{array}{l}\text { "It should never be forgotten that the balanced timbre of any worthy singing } \\
\text { instrument, when coupled with understanding of textual nuance and musical } \\
\text { line, is already emotive and expressive." }\end{array}$ & 126 \\
\hline $39 b$ & $\begin{array}{l}\text { "A coach is not there to teach the singer the music, but to help him or her find } \\
\text { freedom of musical expression through proper linguistic flow, phrase } \\
\text { movement, textual insight, and stylistic security." }\end{array}$ & 133 \\
\hline $40 b$ & $\begin{array}{l}\text { "It is futile to speak of joyful singing when the technical means for expressing } \\
\text { emotion are not present." }\end{array}$ & 134 \\
\hline $41 b$ & $\begin{array}{l}\text { "In short, the substance of vocal technique must be assimilated before any } \\
\text { high level of artistic expression is possible." }\end{array}$ & 135 \\
\hline $42 b$ & $\begin{array}{l}\text { "One of a singer's chief assets is the ability to visualize, to see clearly and } \\
\text { distinctly with the inner eye the dramatic and emotional situation of a song. } \\
\text { This mental picture must be sharper than reality itself because it transcends } \\
\text { reality." }\end{array}$ & 140 \\
\hline $43 b$ & $\begin{array}{l}\text { "As with every physical skill, coordination comes about through the repetition } \\
\text { of kinesthetic responses conditioned by mental awareness. Such skill is not } \\
\text { acquired through bouts of emotional indulgence during which the singer } \\
\text { "feels" the text and the music and experiences cathartic emotional bathing. No } \\
\text { matter how gratifying such sessions may be as forms of self-expression, they } \\
\text { contribute little to the acquisition of technical proficiency that permits true } \\
\text { communication." }\end{array}$ & 149 \\
\hline $44 b$ & $\begin{array}{l}\text { "A singing personality, and there is such a thing, can be the most imaginative } \\
\text { and expressive in the world, but if the vocal instrument is not at a high level of } \\
\text { technical proficiency, the world will never know those qualities." }\end{array}$ & 149 \\
\hline $45 b$ & $\begin{array}{l}\text { "It is essential for the singer to learn the language of the body and the impact } \\
\text { of facial expressions as it is to learn how to accomplish the even vocal scale." }\end{array}$ & 150 \\
\hline $46 b$ & $\begin{array}{l}\text { "Physical movement, and the equally important ability to achieve physical } \\
\text { quietude, play important roles in releasing the body and voice for emotive } \\
\text { expression." }\end{array}$ & 150 \\
\hline $47 b$ & $\begin{array}{l}\text { "Dramatic training is as essential to the singer as to the actor. Before } \\
\text { dismissing any vocally talented singer as lacking in 'imagination,' the teacher } \\
\text { should explore technical routes available for the externalization of internal } \\
\text { emotion." }\end{array}$ & 151 \\
\hline $48 b$ & $\begin{array}{l}\text { "More times than not, the lack of communication stems not from the inability } \\
\text { of the singer to feel the emotional impact of text and drama, but from the lack } \\
\text { of technical means to deliver those emotions." }\end{array}$ & 151 \\
\hline $49 b$ & $\begin{array}{l}\text { "An understanding of human needs and emotions is essential to artistic } \\
\text { expression." }\end{array}$ & 157 \\
\hline $50 b$ & $\begin{array}{l}\text { "It is often overlooked that vocal timbre is emotive, and that every vocalise } \\
\text { should be treated as a musical expression, an emission of sound that in itself is } \\
\text { communicative." }\end{array}$ & 180 \\
\hline $51 b$ & $\begin{array}{l}\text { "A less than beautiful sound communicates nothing of beauty. ('Vocal } \\
\text { colouration' that produces ugly sound is neither musical nor expressive)." }\end{array}$ & 180 \\
\hline
\end{tabular}




\begin{tabular}{|l|l|l|}
\hline $52 b$ & $\begin{array}{l}\text { "Even musical expression and textual communication need to be } \\
\text { systematically practiced." }\end{array}$ & 181 \\
\hline $53 b$ & $\begin{array}{l}\text { "Student and teacher creatively share in analyzing and determining what } \\
\text { remains lacking in technique and expression." }\end{array}$ & 181 \\
\hline $54 b$ & $\begin{array}{l}\text { "Artistic insight and intuition cannot be realized if the technical tools for their } \\
\text { expression are lacking." }\end{array}$ & 187 \\
\hline $55 b$ & $\begin{array}{l}\text { "No singer can hope to exhibit artistry until the basic rules of the craft have } \\
\text { been mastered." }\end{array}$ & 187 \\
\hline $56 b$ & $\begin{array}{l}\text { "Perhaps the most difficult person to teach is that singer who is convinced that } \\
\text { innate artistry and expressive power are unique personal possessions, and that } \\
\text { emotion and feeling equal communication." }\end{array}$ & 188 \\
\hline $57 b$ & $\begin{array}{l}\text { "The singer who assumes that art exists independently of discipline, what } \\
\text { wants to stand up and emote without routine technical habits, lack insight..." }\end{array}$ & 188 \\
\hline $58 b$ & $\begin{array}{l}\text { "When the body is free, spiritual and artistic expression can be realized } \\
\text { through the singing voice." }\end{array}$ & 204 \\
\hline $59 b$ & $\begin{array}{l}\text { "The only reason for any form of technical vocal study is to be able to sing in } \\
\text { an artistic and communicative manner. Function and art cannot be long } \\
\text { separated at any phase of development." }\end{array}$ & 302 \\
\hline $60 b$ & $\begin{array}{l}\text { "The laboratory tests that inform the scientific approach to voice pedagogy } \\
\text { accelerates the removal of technical barriers so that artistry can become the } \\
\text { singer's primary concern." }\end{array}$ \\
\hline
\end{tabular}




\section{WORKS CITED}

Abelson, T. I., and Hicks, D. M. (2007). Richard Miller: Excellence and collaboration. Journal of Singing. Retrieved from www.nats.org

Adachi, M., and Trehub, S. E. (2000). Decoding the expressive intentions in children's songs. Music Perception, 18, 213-224.

Babel, M.E. (2009). Phonetic and social selectivity in speech accommodation. (Doctoral dissertation) Retrieved from ProQuest Dissertations and Theses Database. (Order No. $3382831)$.

Boylan, P. (2009). Accommodation theory revisited. In M. Fatigante, L. Mariottini \& M.E. Sciubba (Eds.), Lingua e società (pp.287- 303). Rome: FancoAngeli.

Bozeman, K. (2007). A case for voice science in the voice studio. Journal of Singing. Retrieved from www.nats.org

Carlos, C. S., and Yalamanchi, M. (2012). Intention analysis for sales, marketing and customer service. Retrieved from http://www.aiaioo.com/publications/coling2012.pdf

Chapman, J.L. (2007). Singing and teaching singing. A holistic approach to classical voice. Journal of Singing, 597-598. Retrieved from www.nats.org.

Chiles, T. (2014). Course outlines. Don Wright Faculty of Music. Retrieved from http://www.music.uwo.ca/students/undergraduate/departments/music_performance/cours e\%20outline\%2013-14\%20pdf/lessonsChiles.pdf

Cohen, A.J. (2008). Advancing interdisciplinary research in singing through a shared digital repository. In Proceedings of the ASA-EAA symposium on Interdisciplinary Research in the Science of Singing (pp. 3177-3182). Retrieved from http://webistem.com/acoustics2008/acoustics2008/cd1/data/articles/001790.pdf 
Coupland, N., Coupland, J., Giles, H., \& Henwood, K. (1988). Accommodating the elderly: Invoking and extending a theory. Language in Society, 17, 1-41. doi: $10.1017 / \mathrm{S} 0047404500012574$

Coupland, N., Coupland, J., \& Giles, H. (1991). Accommodation theory: Communication, context, and consequence. In H. Giles, J. Coupland \& N. Coupland (Eds.), Contexts of accommodation: Developments in applied sociolinguistics (pp.1-68). New York: Cambridge University Press.

De Poli, G. (2004). Methodologies for expressiveness modeling of and for music performance. Journal of New Music Research, 33, 189-202. doi: $10.1080 / 0929821042000317796$

Dilworth, John. (2004). Artistic expression as interpretation. British Journal of Aesthetics, 44, 10-28.

Edidin, A. (2000). Artistry in classical musical performance. British Journal of Aesthetics, 40, 317-325.

Edwin, R. (2007). What Richard Miller hath wrought. Journal of Singing. Retrieved from www.nats.org.

Ekman, P. (1997). Should we call it expression or communication? Journal of Innovation, 10, 333-344.

Gabrielsson, A. \& Juslin, P.N. (1996). Emotional expression in music performance: Between the performer's intention and the listener's experience. Psychology of Music and Music Education, 24, 68-91. doi: 10.1177/0305735696241007 Gassi, G. (2014). Course outlines. Don Wright Faculty of Music. Retrieved from 
http://www.music.uwo.ca/students/undergraduate/departments/music_performance/cours e\%20outline\%2013-14\%20pdf/lessonsGassi.pdf

Geringer, J.M. \& Sasanfar, J.K. (2013). Listener perception of expressivity in collaborative performances containing expressive and unexpressive playing by the pianist. Journal of Research in Music Education, 6, 160-174. doi:

$10.1177 / 0022429413485246$

Gorn, G. J. (1982). The effects of music in advertising on choice behaviour: A classical conditioning approach. Journal of Marketing, 46, 94-101. doi: 10.2307/1251163

Hill, L.B. \& Kennan, W.R. (1980). Kiowa forty-nine singing: A communication perspective. International Journal of Intercultural Relations, 4, 149-165.

Kiesgen, P. (2007). How Richard Miller changed the way we thing about singing. Journal of Singing. Retrieved from www.nats.org

Lukkau, P. (2004). Instrumental music teachers' views on expressivity: A report from music conservatoires. Music Education Research, 6, 45-56. doi: $10.1080 / 1461380032000182821$

Meyerhoff, M. (1998). Accommodating your data: The use and misuse of accommodation theory in sociolinguistics. Language \& Communication, 18, 205-225. doi: http://www.sciencedirect.com/science/article/pii/S0271530998000068

Miller, R. (1996). On the art of singing. New York: Oxford University Press Inc.

Miller, R. (2000). Training soprano voices. New York: Oxford University Press Inc.

Mortimore, P. (1999). Understanding pedagogy: And its impact on learning. California: SAGE Publications Company.

Nafisi, J. (2010). Gesture as a tool of communication in the teaching of singing. 
Australian Journal of Music Education, 2, 103-116.

Nederland, M. (2007). One-to-one teaching as cultural practice: Two case studies from an academy of music. Music Education Research, 9, 399-416. doi:

$10.1080 / 14613800701587761$

Pavlicevic, M. (2000). Improvisation in music therapy: Human communication in sound. Journal of Music Therapy, 37, 269-285.

Royal Conservatory of Music, The. (2012). Voice syllabus 2012 edition. Mississauga: The Frederick Harris Music Co., Limited

Silverman, M. (2008). A performer's creative processes: Implications for teaching and learning musical interpretation. Music Education Research, 10, 249-269. doi: $10.1080 / 14613800802079114$

Western University. Audition information for voice. Retrieved from http://www.music.uwo.ca/programs/undergraduate/future_students/audition_instruments/ voice.html 